\title{
Effects of the protracted feeding of copper sulphate-supplemented diets to laying, domestic fowl on egg production and on specific tissues, with special reference to mineral content
}

\author{
BY N. JACKSON AND MARY H. STEVENSON \\ Department of Agricultural and Food Chemistry, The Queen's University of Belfast, Newforge \\ Lane, Belfast BT9 5 PX, Northern Ireland, UK and Department of Agriculture for Northern \\ Ireland \\ AND G. MCC. KIRKPATRICK \\ Department of Agriculture for Northern Ireland, Newforge Lane, Belfast BT9 ${ }_{5} P X$, \\ Northern Ireland, UK
}

(Received 23 January 1979 - Accepted 2 March 1979)

I. Two experiments are reported. In both experiments a cereal-based diet containing $5 \mathrm{mg}$ copper $/ \mathrm{kg}$ was fed to two breeds of laying hens for $336 \mathrm{~d}$. In Expt I four other groups were given this diet with the addition of $\mathrm{CuSO}_{4} \cdot 5 \mathrm{H}_{2} \mathrm{O}$ to give added levels of $200,400,600$ and $800 \mathrm{mg} \mathrm{Cu} / \mathrm{kg}$ diet. In Expt 2 the levels of added dietary $\mathrm{Cu}$ used were $100,200,300$ and $400 \mathrm{mg} / \mathrm{kg}$.

2. In Expt I records were kept of food intake, water intake, body-weight and egg production for eight $28 \mathrm{~d}$ periods and body-weight and egg number only were recorded for the full twelve periods. In Expt 2 full records, excluding water intake, were taken for all twelve periods.

3. Food and water intake showed a quadratic response to level of added dietary $\mathrm{Cu}$, being enhanced at lower levels and depressed at higher levels of addition.

4. There was a quadratic response of total egg weight, mean egg weight and egg number to added dietary $\mathrm{Cu}$. In Expt I egg number was maximum at $235 \mathrm{mg}$ added $\mathrm{Cu} / \mathrm{kg}$ diet for Warren Studler SSL (breed $\mathrm{I}$ ) and at $170 \mathrm{mg}$ added $\mathrm{Cu} / \mathrm{kg}$ diet for Shaver 288 (breed 2). In Expt 2 no breed effect occurred, the maximum egg number being calculated to occur at $176 \mathrm{mg}$ added $\mathrm{Cu} / \mathrm{kg}$ diet.

5. Depression of body-weight gain occurred at high levels of $\mathrm{Cu}$ addition. The depression of liver and oviduct weight found at high levels of addition appeared to be directly related to body-weight. A marked amount of feather loss also occurred at a high inclusion of $\mathrm{CuSO}_{4}$ in the diet.

6. The reproductive systems of the hens did not appear to be adversely affected at the levels of additive used. Gross and microscopic examination of specific tissues revealed no pathological effects although gizzard and intestinal weights were increased and caecal weight decreased by high levels of added $\mathrm{Cu}$. Those aspects of the blood chemistry examined did not reveal any consistent effect between the two experiments.

7. The liver $\mathrm{Cu}$ analyses indicate that between 600 and $800 \mathrm{mg}$ added $\mathrm{Cu} / \mathrm{kg}$ diet the liver $\mathrm{Cu}$ concentration rises sharply. Both liver $\mathrm{Fe}$ and $\mathrm{Zn}$ concentrations showed a positive linear response to added dietary $\mathrm{Cu}$. In the kidney $\mathrm{Cu}$ and $\mathrm{Zn}$ concentrations were increased but only to a limited extent, while the concentration of $\mathrm{Fe}$ was unaffected.

The effects of adding copper compounds to the diet of the fowl have been briefly reviewed (Jackson, I977). The growth and food conversion responses of adding $\mathrm{Cu}$ compounds to the diet of the growing bird have been statistically analysed (Fisher et al. 1971 ; Fisher, 1973). The ir results indicated a quadratic response of body-weight gain and food conversion efficiency to added dietary $\mathrm{Cu}$. This was clearly defined at higher levels due to growth depression, but the positive response at lower levels (up to $300 \mathrm{mg} \mathrm{Cu} / \mathrm{kg}$ diet) was considered to be real. There was a maximum growth stimulation at approximately $170 \mathrm{mg} \mathrm{Cu} / \mathrm{kg} \mathrm{diet}$ and a maximum food conversion at $140 \mathrm{mg} / \mathrm{kg}$.

In the broiler, Janssen (I97I) and Fisher et al. (1973) found copper sulphate to cause lesions of the gizzard lining and Jensen \& Maurice (1978) found the caeca of broilers given up to $250 \mathrm{mg}$ additional $\mathrm{Cu} / \mathrm{kg}$ diet to be distended and to contain dark, pasty contents with a $\mathrm{Cu}$ level of $5000 \mathrm{mg} / \mathrm{kg}$ dry matter (DM). They also found liver weight and the lipid 
content of liver DM to be increased. Bubien et al. (I97I) found that giving a single dose of $800 \mathrm{mg} \mathrm{Cu}$, as the sulphate, to adult male birds frequently caused death within $2 \mathrm{~d}$, while I $60 \mathrm{mg} / \mathrm{d}$ proved lethal after up to $34 \mathrm{~d}$.

There have been few studies on the effect of added $\mathrm{Cu}$ as salts or oxides in the diet of the laying hen. In a recent study (Jackson, 1977) $\mathrm{Cu}$, as sulphate, was added to the diet of laying hens up to a level of $1920 \mathrm{mg} / \mathrm{kg}$ diet.

Food and water intakes were depressed by 960 and $1920 \mathrm{mg} / \mathrm{kg}$ levels of added dietary $\mathrm{Cu}$ and water intake was increased by $240 \mathrm{mg}$ added $\mathrm{Cu} / \mathrm{kg}$ diet. Both food and water intakes showed a quadratic relationship with the level of added dietary $\mathrm{Cu}$.

Body-weight gain was decreased by the addition of $\mathrm{Cu}$ and showed a significant linear relationship with the concentration of added $\mathrm{Cu}$ in the diet. Liver and oviduct weights were depressed at 960 and $1920 \mathrm{mg}$ added $\mathrm{Cu} / \mathrm{kg}$ diet.

Liver and oviduct $\mathrm{Cu}$ and iron concentrations were significantly increased by high dietary $\mathrm{Cu}$, and mean total liver and kidney $\mathrm{Cu}$ and $\mathrm{Fe}$ showed an increase, although for the liver this was not statistically significant.

Egg production by hens given added $\mathrm{Cu}$ to a level of $960 \mathrm{mg} / \mathrm{kg}$ in the diet became infrequent and those given $\mathrm{Cu}$ at $1920 \mathrm{mg} / \mathrm{kg}$ ceased laying altogether after $\mathrm{I} 4 \mathrm{~d}$. However, the observations were only carried out for $35 \mathrm{~d}$, which limits their usefulness.

Griminger (1977) found that $\mathrm{Cu}$ supplementation of the diet of laying hens with $2000 \mathrm{mg}$ anhydrous $\mathrm{CuSO}_{4}(796 \mathrm{mg} \mathrm{Cu}) / \mathrm{kg}$ for 2 weeks depressed food intake, body-weight, egg production and eggshell thickness while $1000 \mathrm{mg} \mathrm{Cu}$ as sulphate $/ \mathrm{kg}$ had no effect.

Jensen et al. (1978) found adding extra $\mathrm{Fe}, \mathrm{Cu}$, zinc, manganese and selenium to the diet to affect egg quality significantly, this being reflected in an increase in the Haugh units of the eggs.

Copper acetate, fed in a gelatin capsule to laying hens and providing $100 \mathrm{mg} \mathrm{Cu}$ daily caused weight loss, anaemia and death (Goldberg et al. 1956). Kuznetsov \& Volkov (1974) fed $\mathrm{CuSO}_{4}$ to laying hens for $270 \mathrm{~d}$. They found $148 \mathrm{mg}$ added $\mathrm{Cu} / \mathrm{kg}$ diet to increase liver $\mathrm{Cu}$ by approximately $50 \%$ and plasma $\mathrm{Cu}$ by $36 \%$, while liver and plasma Fe were also temporarily increased.

The studies reported in the present paper were designed to look at the longer-term effects of $\mathrm{CuSO}_{4} \cdot 5 \mathrm{H}_{2} \mathrm{O}$ fed as an additive in the diet of the laying hen, both in terms of productivity and of the effect of the additive on specific tissues of the fowl. Expt I investigated the effect of feeding $\mathrm{CuSO}_{4} \cdot 5 \mathrm{H}_{2} \mathrm{O}$ to a moderately high level $(800 \mathrm{mg}$ added $\mathrm{Cu} / \mathrm{kg}$ ) in the diet of the laying hen. Expt 2 was carried out to look in more detail at the effects of adding $\mathrm{Cu}$, as sulphate, in the range $0-400 \mathrm{mg}$ added $\mathrm{Cu} / \mathrm{kg}$ diet.

\section{EXPERIMENTAL}

\section{Expt I}

Seventy pullets, 17 weeks old and comprising equal numbers of Warren Studler SSL (breed I) and Shaver 288 (breed 2) birds, previously vaccinated against Mareks disease, infectious bronchitis and epidemic tremors, were caged in galvanized-iron cages with individual feeders and water troughs. They were given a cereal-based control diet (Table I) until the commencement of the experiment and subjected to a lighting programme of $17 \mathrm{~h}$ light- $7 \mathrm{~h}$ darkness. The maximum temperature recorded in the poultry house during the experiment was $27^{\circ}$ on 18 August 1976 and the minimum $14^{\circ}$ on II January 1977. The Cu was added to the diets as finely ground $\mathrm{CuSO}_{4} \cdot 5 \mathrm{H}_{2} \mathrm{O}$. The fineness of the additive has previously been specified (Jackson, 1977). At 24 weeks old (2 August 1976), when all the birds were in lay, they were randomized into five treatment groups. The hens on treatment I were given the control diet and the hens in treatments $2-5$ given this diet with the addition of $200,400,600$ or $800 \mathrm{mg} \mathrm{Cu} / \mathrm{kg}$ diet respectively. The appropriate experimental diet and 
Table I. Expts I and 2. Composition $(\mathrm{g} / \mathrm{kg})$ and analysis of the control diet

\begin{tabular}{lr} 
Constituent & \\
Ground maize & $600 \cdot 0$ \\
Ground wheat & $74 \cdot 2$ \\
Fish meal & $26 \cdot 1$ \\
Soya-bean meal & $187 \cdot 5$ \\
Grass meal & $25 \cdot 0$ \\
Limestone flour & $71 \cdot 9$ \\
Dicalcium phosphate & $9 \cdot 8$ \\
Common salt & $3 \cdot 0$ \\
Vitamin-mineral supplement (copper-free)* & $2 \cdot 5$ \\
Total & $1000 \cdot 0$ \\
Analysis & \\
Dry matter $(\mathrm{g} / \mathrm{kg})$ & 894 \\
Metabolizable energy $(\mathrm{MJ} / \mathrm{kg})$ & $1 \mathrm{r} \cdot 9 \dagger$ \\
Crude $\mathrm{protein}(\mathrm{nitrogen} \times 6 \cdot 25)(\mathrm{g} / \mathrm{kg})$ & 162 \\
Diethyl ether extract $(\mathrm{g} / \mathrm{kg})$ & $26 \cdot 1$ \\
Crude fibre $(\mathrm{g} / \mathrm{kg})$ & $28 \cdot 0$ \\
Calcium $(\mathrm{g} / \mathrm{kg})$ & $33 \cdot 6$ \\
Phosphorus $(\mathrm{g} / \mathrm{kg})$ & $5 \cdot 3$ \\
Copper $(\mathrm{mg} / \mathrm{kg})$ & 5 \\
Zinc $(\mathrm{mg} / \mathrm{kg})$ & 106 \\
Iron (mg $/ \mathrm{kg})$ & 285 \\
\hline
\end{tabular}

* The vitamin-mineral supplement provided $(\mathrm{mg} / \mathrm{kg}$ diet): 2.4 retinol; 50 cholecalciferol; 3.4 riboflavin; $5(\mu \mathrm{g})$ cyanocobalamin; $2.7 \alpha$-tocopherol; I. 5 menadione sodium bisulphite; Io nicotinic acid; 4.5 Ca-Dpanthothenate; 115 choline chloride; $40 \mathrm{Fe}, 65$ manganese; 0.6 iodine; $50 \mathrm{Zn}$; 0.1 selenium.

$\uparrow$ Calculated.

water were available ad lib., the latter containing $0.1 \mathrm{mg} \mathrm{Cu} / \mathrm{l}$. Food and water intakes were recorded daily for the first 2 weeks and thereafter food was recorded for each period and water on a weekly basis. Egg production was recorded daily and egg weight twice weekly. The full experimental results were recorded for eight $28 \mathrm{~d}$ periods. Body-weights and egg numbers only were recorded for a further four periods.

The birds were slaughtered by decapitation at the end of the twelfth period and blood analysed for packed cell volume (PCV), haemoglobin ( $\mathrm{Hb}$ ) and $\mathrm{Cu}$ contents, the latter by atomic absorption spectroscopy subsequent to wet ashing with concentrated nitric and perchloric acids (Thompson \& Blanchflower, I97I). Blood serum was analysed for aspartate aminotransferase (AAT; EC 2.6. I I) level by the method of Bergmeyer \& Bernt (1965), one international unit referring to the oxidation of I $\mu \mathrm{mol} \mathrm{NADPH} / \mathrm{min}$ at $37^{\circ}$. The liver, kidneys, oviduct and gizzard were removed and weighed. The livers were analysed for lipid content by the method of Folch et al. (1957). The remainder of the digestive tract, including the caeca, was removed, washed internally with tap-water, lightly dried on blotting paper and the length and weight recorded. Liver and kidney samples were analysed for $\mathrm{Cu}, \mathrm{Fe}$ and $\mathrm{Zn}$ content by atomic absorption spectroscopy after solution of the ash in dilute hydrochloric acid. The results were analysed for treatment and breed effects, the mean values for each breed being presented when interaction was found to occur.

Portions of the liver, kidney, spleen, adrenal glands, oviduct and ovary were fixed in buffered neutral formalin $(100 \mathrm{ml} / \mathrm{l})$, processed by standard methods and embedded in paraffin wax. The gizzard and a portion of gut from the anterior end of the small intestine were also treated in this way. Sections cut at $5 \mu \mathrm{m}$ were stained by haematoxylin and eosin ( $\mathrm{H} \& \mathrm{E}$ ) and selected sections were stained by the rubeanic acid (dithio-oxamide) and by the 5-p-dimethylaminobenzylidine rhodamine method as outlined by Linquist (1969) for $\mathrm{Cu}$ and by the periodic acid-Schiff (PAS) method for glycogen. 


\section{Expt 2}

One hundred and sixty-eight hens, I 7 weeks old and comprising equal numbers of Warren Studler SSL (breed I) and Shaver 288 (breed 2) were caged and fed as for Expt I. At 24 weeks of age ( 2 August 1976) they were randomized and subjected to the following dietary treatments: control diet (treatment I) as for Expt $\mathrm{I}$, and this diet to which was added roo, 200,300 or $400 \mathrm{mg} \mathrm{Cu} / \mathrm{kg}$ diet. Most of the hens were laying at the commencement of the experiment. Food intake, egg production, egg weight and body-weight were recorded as for Expt. I The recorded daily temperatures showed a maximum of $28^{\circ}$ on I 8 August 1976 and a minimum of $15^{\circ}$ on I I January I977. After twelve $28 \mathrm{~d}$ periods the birds were slaughtered. Blood was analysed and organs removed and examined as for Expt I, both total oviduct and shell gland being investigated. Assays were made of the $\mathrm{Cu}, \mathrm{Fe}$ and $\mathrm{Zn}$ concentrations of the oviduct minus the shell gland.

\section{RESULTS}

\section{Expt $\mathrm{I}$}

One bird in treatment 2 died after $7 \mathrm{~d}$. The death was not attributed to the experimental treatment and the missing-plot technique was applied. The two highest $\mathrm{Cu}$ treatments resulted in an obvious increase in feather loss by approximately $50 \%$ of the birds.

The results for water and food intake, food conversion, egg production and body-weight for Expt I are presented in Table 2. For the eight fully recorded periods body-weight gain showed a significant negative linear relationship $(P<0.00 \mathrm{I})$ with the dietary content of added $\mathrm{Cu}$. The two groups being given the highest levels of added $\mathrm{Cu}$ showed almost no body-weight change, while the other three treatments caused an increase in body-weight which was greatest for treatments I and 2. The daily food intake records for the first 2 weeks of the experiment showed that treatment 2 birds had the highest food intake from the commencement of the experiment while the other three levels of $\mathrm{Cu}$ addition caused a food intake depression. Food intake was highest at $200 \mathrm{mg}$ added $\mathrm{Cu} / \mathrm{kg}$ (treatment 2) in all periods, a quadratic response in relation to added dietary $\mathrm{Cu}$ being evident in every period. There was a marked depression of intake at the two highest levels of added $\mathrm{Cu}$. This food intake depression resulted in the $\mathrm{Cu}$ intake of the hens given diet 5 being increased only $7 \%$ above that of those offered diet 4 , even though the level of $\mathrm{Cu}$ in diet 5 was one third greater than that in diet 4 . Initially, the effect on water intake was a depression for the breed 2 birds receiving $800 \mathrm{mg}$ added $\mathrm{Cu} / \mathrm{kg}$ and an increase for the breed I birds receiving this diet. The total water intake showed a quadratic response $(P<0.05)$ to added dietary $\mathrm{Cu}$, the average water intake for treatment 3 being highest in six periods and that for treatment 5 consistently the lowest in all periods.

In all eight periods there was a marked quadratic ( $P<0.001$ over all) response of both egg number and total egg weight to the level of added $\mathrm{Cu}$. Egg number, but not total egg weight, showed a diet $\times$ breed interaction. The maximum egg number for the breed $\mathrm{I}$ and 2 hens was calculated to occur at $235 \mathrm{mg}$ and $170 \mathrm{mg}$ added $\mathrm{Cu} / \mathrm{kg}$ diet respectively. Total egg weight was greatest for treatment 2 in seven of the eight periods, the maximum occurring at $\mathrm{I} 9 \mathrm{I} \mathrm{mg}$ added $\mathrm{Cu} / \mathrm{kg}$ diet.

The response of mean period-mean egg weight to added dietary $\mathrm{Cu}$ was quadratic $(P<0.05)$. Treatment 2 mean egg weight was highest in seven of the eight periods while over-all treatment 5 mean egg weight was statistically lower than that of all other treatments. Statistical analysis showed the maximum mean period-mean egg weight to occur at $235 \mathrm{mg}$ added $\mathrm{Cu} / \mathrm{kg}$ diet.

Over-all food conversion efficiency ( $\mathrm{kg}$ eggs $/ \mathrm{kg}$ feed) showed a quadratic response $(P<0.00 \mathrm{I})$ to the level of added $\mathrm{Cu}$. A diet $\times$ breed interaction was present. For both 


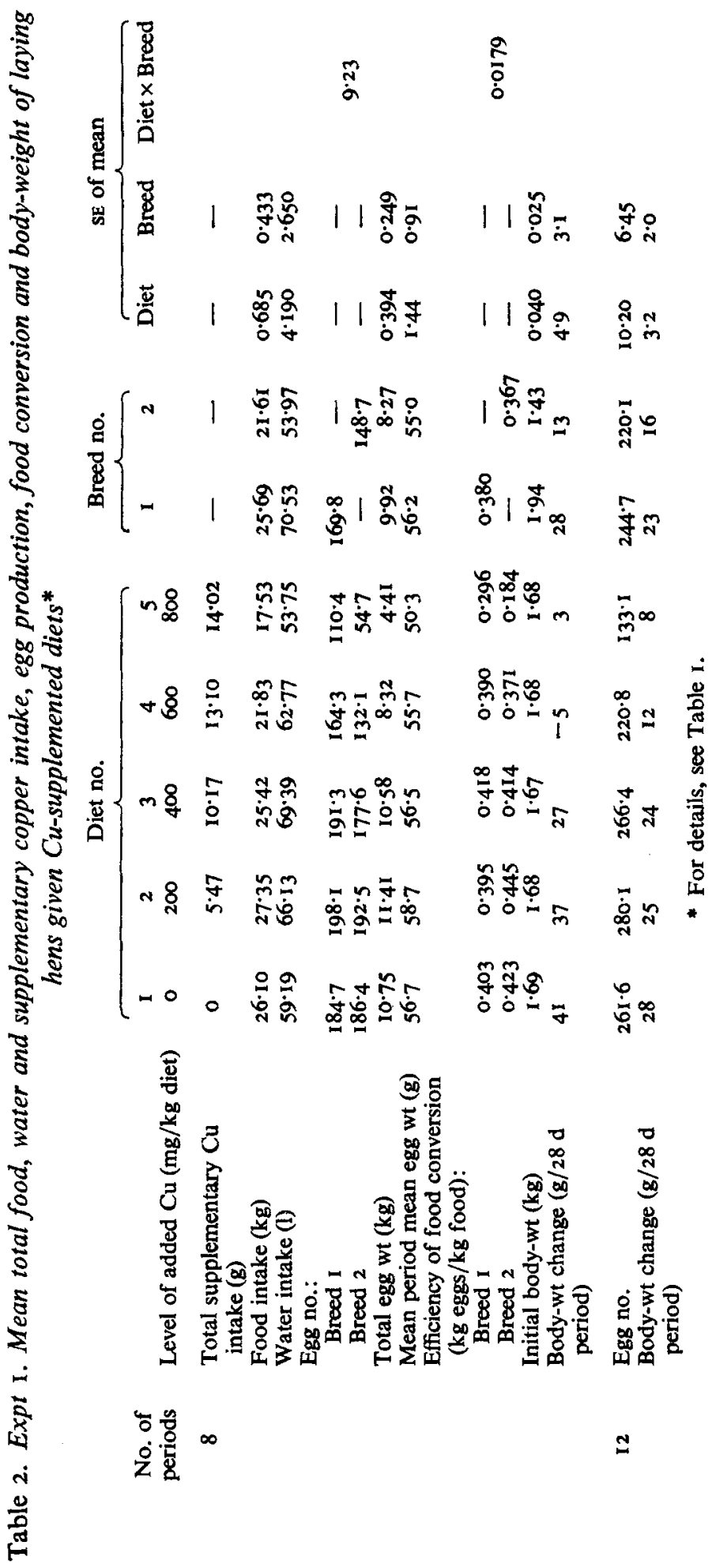


breeds there was no obvious evidence of any differences in food conversion between treatments $\mathrm{I}, 2$ and $3(0,200$ and $400 \mathrm{mg} / \mathrm{kg})$ but the mean value for treatment $4(600 \mathrm{mg} / \mathrm{kg})$ was generally poorer than for treatments $\mathrm{I}, 2$ and 3 while for treatment $5(800 \mathrm{mg} / \mathrm{kg})$ the efficiency of food conversion was significantly depressed $(P<0.00 \mathrm{I})$ in seven of the eight periods. The maximum food conversion efficiency was found to occur at 263 and $220 \mathrm{mg}$ added $\mathrm{Cu} / \mathrm{kg}$ diet for breeds $\mathrm{I}$ and 2 respectively.

Over the twelve periods egg number and body-weight gain showed the same general trends as over the first eight periods. Egg number was greatest for treatment 2 for ten of the twelve periods. Treatment 2 gave a response of $7 \%$ over the control and the hens in treatments 4 and 5 showed a depression in egg number of 16 and $50 \%$ respectively compared to the control.

The mean blood $\mathrm{Hb}, \mathrm{PCV}, \mathrm{Cu}$ and serum $\mathrm{AAT}$ values at slaughter are presented in Table 3. The mean blood $\mathrm{Hb}$ for treatment 5 was significantly less than for treatments 2 and 3. PCV showed a quadratic relationship with level of added $\mathrm{Cu}$, the values for treatments 2 and 3 being significantly $(P<0.00 \mathrm{I})$ greater than for treatment $\mathrm{I}$. The blood $\mathrm{Cu}$ analyses of variance showed no significant differences. The mean serum AAT value was highest for treatment 3 but no statistically significant difference was present.

Liver and kidney fresh and dry weights and DM results are given in Table 4 together with the liver lipid concentrations and total contents, while the $\mathrm{Cu}, \mathrm{Fe}$ and $\mathrm{Zn}$ values for these organs are presented in Table 5.

Liver fresh and dry weights and kidney dry weight showed a negative linear response ( $P<0.00 \mathrm{I}, P<0.00 \mathrm{I}$ and $P<0.05$ respectively) to the level of added $\mathrm{Cu}$, the mean values being increased, although not significantly, by the lowest $(200 \mathrm{mg} / \mathrm{kg})$ level of added $\mathrm{Cu}$. The higher levels of added $\mathrm{Cu}$ caused a statistically significant depression of the dry weights of the liver and kidney, but the mean kidney fresh weight was higher for all $\mathrm{Cu}$ treatments than for the control, although the effect was not statistically significant.

Liver fresh weight, as $\mathrm{g} / \mathrm{kg}$ body-weight, was highest for treatment 2 , which was significantly higher than for treatment $3(P<0.00 \mathrm{I})$ and treatment $5(P<0.0 \mathrm{I})$. Kidney fresh weight $(\mathrm{g} / \mathrm{kg}$ body-weight) had a linear relationship to added dietary $\mathrm{Cu}(P<0.0 \mathrm{I})$ and was increased above the control value by all $\mathrm{Cu}$ treatments. Liver DM content had a negative linear relationship $(P<0.00 \mathrm{I})$ to the level of added $\mathrm{Cu}$, being highest for treatment 2 and significantly depressed below the control value in treatments 3 and 5 . Kidney DM $(\mathrm{mg} / \mathrm{g})$ had a negative linear relationship $(P<0.05)$ with the level of added $\mathrm{Cu}$, all the mean values being lower than for the control, the effect being statistically significant for treatments 4 and 5 .

The liver lipid concentration and total content decreased linearly (both $P<0.001$ ) with the level of added dietary $\mathrm{Cu}$.

Entire and lipid-free liver $\mathrm{DM} \mathrm{Cu}$ concentrations (Table 5) were increased by added dietary $\mathrm{Cu}(P<0.00 \mathrm{I})$, showing a quadratic relationship $(P<0.00 \mathrm{I})$, treatment 5 being significantly higher $(P<0.00 \mathrm{I})$ than all other treatments. This concentration effect was reflected in total liver $\mathrm{Cu}$ content, the quadratic effect being highly significant.

The effect of dietary added $\mathrm{Cu}$ on liver $\mathrm{DM}$ Fe concentration was linear $(P<0.05)$, but the total $\mathrm{Fe}$ content of the liver DM was not affected by the diet.

The $\mathrm{Zn}$ concentration in liver showed a positive linear relationship to added dietary $\mathrm{Cu}$ $(P<0.00 \mathrm{I})$, although only treatment $5 \mathrm{Zn}$ content was significantly greater than for treatment $\mathrm{I}$. The total liver $\mathrm{Zn}$ content was not affected.

Kidney $\mathrm{Cu}$ concentration was increased linearly $(P<0.00 \mathrm{I})$ by added dietary $\mathrm{Cu}$ although total content was not affected. Kidney $\mathrm{Fe}$ concentration and content were not affected while $\mathrm{Zn}$ concentration increased linearly $(P<0.00 \mathrm{I})$ and total $\mathrm{Zn}$ content was not affected by added dietary $\mathrm{Cu}$.

The oviduct, gizzard, intestinal and caecal results appear in Table 6 . There was a 
Table 3. Expt I. Mean blood haemoglobin $(H b)$, packed cell volume (PCV), copper and serum aspartate aminotransferase (AAT; EC 2.6.I.I) at slaughter for laying hens given $\mathrm{Cu}$ supplemented diets*

\begin{tabular}{|c|c|c|c|c|c|c|c|c|c|}
\hline \multirow[b]{3}{*}{ Level of added $\mathrm{Cu}(\mathrm{mg} / \mathrm{kg})$} & \multicolumn{5}{|c|}{ Diet no. } & \multirow{2}{*}{\multicolumn{2}{|c|}{ Breed no. }} & \multirow{2}{*}{\multicolumn{2}{|c|}{ SE of mean }} \\
\hline & I & $?$ & & 1 & & & & & \\
\hline & $\ldots 0$ & 200 & 400 & 600 & 800 & I & 2 & Diet & Breed \\
\hline $\begin{array}{l}\mathrm{Hb}(\mathrm{g} / \mathrm{l}) \\
\mathrm{PCV}\end{array}$ & $\begin{array}{c}82.8 \\
0.23\end{array}$ & $\begin{array}{c}89 \cdot 6 \\
0.29\end{array}$ & $\begin{array}{c}88.9 \\
0.29\end{array}$ & $\begin{array}{c}83.5 \\
0.25\end{array}$ & $\begin{array}{c}78 \cdot 6 \\
0.25\end{array}$ & $\begin{array}{c}84.3 \\
0.27\end{array}$ & $\begin{array}{c}85.1 \\
0.26\end{array}$ & $\begin{array}{l}3.03 \\
0.010\end{array}$ & $\begin{array}{l}I .91 \\
0.006\end{array}$ \\
\hline & 304 & 283 & 275 & 316 & 286 & 302 & 283 & $20 \cdot 7$ & $13 \cdot 1$ \\
\hline Serum AAT (iu $\dagger / 1)$ & 224 & 224 & 276 & 247 & 226 & $25 \mathrm{I}$ & 227 & $22 \cdot 5$ & $14 \cdot 3$ \\
\hline
\end{tabular}

* For details, see Table I.

$\dagger$ One international unit refers to the oxidation of $\mathrm{I} \mu \mathrm{mol} \mathrm{NADPH} / \mathrm{min}$ at $37^{\circ}$.

Table 4. Expt I. Liver and kidney fresh and dry weight, dry matter (DM) concentration and liver lipid levels for laying hens given Cu-supplemented diets*

\begin{tabular}{|c|c|c|c|c|c|c|c|c|c|}
\hline \multirow[b]{3}{*}{ Level of added $\mathrm{Cu}(\mathrm{mg} / \mathrm{kg})$} & \multicolumn{5}{|c|}{ Diet no. } & \multirow{2}{*}{\multicolumn{2}{|c|}{ Breed no. }} & \multirow{2}{*}{\multicolumn{2}{|c|}{$\mathrm{SE}$ of mean }} \\
\hline & \multirow[b]{2}{*}{$\begin{array}{l}I \\
0\end{array}$} & \multirow{2}{*}{$\begin{array}{c}2 \\
200\end{array}$} & \multirow{2}{*}{$\begin{array}{c}3 \\
400\end{array}$} & \multirow{2}{*}{$\begin{array}{c}4 \\
600\end{array}$} & \multirow{2}{*}{$\begin{array}{c}5 \\
800\end{array}$} & & & & \\
\hline & & & & & & I & 2 & Diet & Breed \\
\hline \multicolumn{10}{|l|}{ Liver wt (g): } \\
\hline Fresh & $43 \cdot 9$ & $48 \cdot 4$ & $34 \cdot I$ & $38 \cdot 2$ & $3 I^{1} \cdot 6$ & $43 \cdot 2$ & $35 \cdot 3$ & $2 \cdot 37$ & $I \cdot 50$ \\
\hline Dry & 16.6 & 19.8 & II.O & $13 \cdot 1$ & $9 \cdot 7$ & 15.4 & 12.6 & $1 \cdot 29$ & 0.82 \\
\hline Fresh ( $(\mathrm{g} / \mathrm{kg}$ body-wt) & $22 \cdot 0$ & $24 \cdot 7$ & $18 \cdot 4$ & $22 \cdot 5$ & 19.8 & $20 \cdot I$ & $23 \cdot 0$ & $\mathrm{I} \cdot \mathbf{2 5}$ & 0.79 \\
\hline Liver DM (mg/g) & 369 & 402 & 317 & 334 & 306 & 343 & 348 & $13 \cdot 3$ & $8 \cdot 4$ \\
\hline $\begin{array}{l}\text { Liver lipid content (mg/g } \\
\text { DM) }\end{array}$ & 364 & 427 & 254 & 266 & 202 & 304 & 300 & $27 \cdot 3$ & $17 \cdot 2$ \\
\hline Total liver lipid content $(\mathrm{g})$ & $6 \cdot 5$ & $9 \cdot 0$ & $3 \cdot I$ & 3.9 & $2 \cdot I$ & $5 \cdot 5$ & $4 \cdot 3$ & 0.88 & 0.56 \\
\hline \multicolumn{10}{|l|}{ Kidney wt (g): } \\
\hline Fresh & 10.4 & $12 \cdot 0$ & II $\cdot 3$ & 10.9 & II $\cdot 3$ & $\mathrm{II} \cdot \mathbf{3}$ & II $\cdot 0$ & 0.69 & 0.43 \\
\hline Dry & $3 \cdot 0$ & $3 \cdot 4$ & $3 \cdot 0$ & $2 \cdot 8$ & $2 \cdot 7$ & $3 \cdot I$ & $2 \cdot 9$ & 0.19 & 0.12 \\
\hline Fresh (g/kg body-wt) & $5 \cdot 30$ & $6 \cdot 24$ & 6.05 & 6.57 & $7 \cdot 22$ & $5 \cdot 31$ & $7 \cdot 24$ & 0.398 & 0.252 \\
\hline Kidney DM (mg/g) & 294 & 282 & 266 & 254 & 242 & 269 & 266 & $12 \cdot 4$ & $7 \cdot 9$ \\
\hline
\end{tabular}

negative linear relationship $(P<0.05)$ between oviduct fresh weight and level of added $\mathrm{Cu}$, but this effect is lost when the results are expressed per $\mathrm{kg}$ body-weight.

Gizzard fresh weight, both the absolute $(\mathrm{g})$ and relative $(\mathrm{g} / \mathrm{kg}$ body-weight) values, showed a positive linear relationship with added dietary $\mathrm{Cu}(P<0.05$ and $P<0.00 \mathrm{I}$ respectively).

Intestinal fresh weight showed a marked linear $(P<0.0 \mathrm{I})$ increase in response to added $\mathrm{Cu}$. This effect was not seen for absolute length but was present for length per unit bodyweight. Caecal weight and length per $\mathrm{kg}$ body-weight showed a marked $(P<0.00 \mathrm{I})$ linear relationship to the added dietary $\mathrm{Cu}$.

Examination of the koilin layer of the gizzard showed no abnormalities either grossly or histologically in any of the birds and the underlying epithelium was intact. Inflammatory or degenerative changes were not seen in the gizzards and examination of the various tissues from birds fed the $\mathrm{CuSO}_{4}$-containing diets showed no significant changes from the tissues of the control birds. Fatty changes were found in the liver of many of the birds and identified by vacuoles in the hepatic cell cytoplasm, and varying small amounts of glycogen were also observed in the hepatic cells. However, these changes showed no correlation with diet. 
Table 5. Expt $\mathrm{I}$. The copper, iron and zinc concentration $(\mu \mathrm{g} / \mathrm{g})$ and contents $(\mu \mathrm{g})$ in liver and kidney of laying hens given Cu-supplemented diets*

Diet no.

Level of added $\mathrm{Cu}$

(mg/kg diet) ...
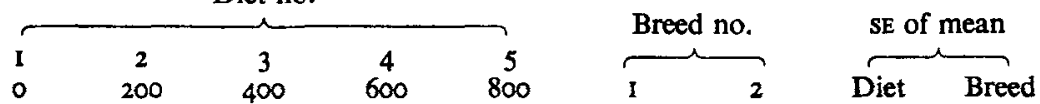

Liver dry matter

Concentration:

$\begin{array}{lccccccccc}\mathrm{Cu} & 9 \cdot 5 & 10 \cdot 5 & 29 \cdot 6 & 40 \cdot 3 & 267 \cdot 0 & 48 \cdot 4 & 94 \cdot 4 & 31 \cdot 24 & 19 \cdot 76 \\ \mathrm{Fe} & 262 & 234 & 376 & 377 & 395 & 336 & 321 & 50 \cdot 2 & 31 \cdot 7 \\ \mathrm{Zn} & 103 & 88 & 158 & 154 & 228 & 164 & 129 & 27 \cdot 8 & 17 \cdot 6 \\ \text { Total content: } & & & & & & & & & \\ \mathrm{Cu} & 150 & 196 & 299 & 444 & 2445 & 480 & 934 & 364 \cdot 1 & 230 \cdot 3 \\ \mathrm{Fe} & 4042 & 4638 & 3700 & 4494 & 3743 & 4536 & 3710 & 517 \cdot 7 & 327 \cdot 4 \\ \mathrm{Zn} & 1610 & 1728 & 1509 & 1875 & 2211 & 2068 & 1505 & 268 \cdot 6 & 169 \cdot 9\end{array}$

Liver lipid-free dry matter

Concentration:

$\begin{array}{lccccccccc}\mathrm{Cu} & 14 \cdot 9 & 18 \cdot 8 & 39 \cdot 2 & 53 \cdot 0 & 336 \cdot 6 & 61 \cdot 9 & 123 \cdot 1 & 39 \cdot 67 & 25 \cdot 09 \\ \mathrm{Fe} & 406 & 422 & 486 & 51 \mathrm{I} & 483 & 475 & 449 & 58 \cdot 4 & 37 \cdot 0 \\ \mathrm{Zn} & 161 & 160 & 205 & 215 & 281 & 227 & 181 & 33 \cdot 9 & 21 \cdot 5\end{array}$

Kidney dry matter

Concentration:

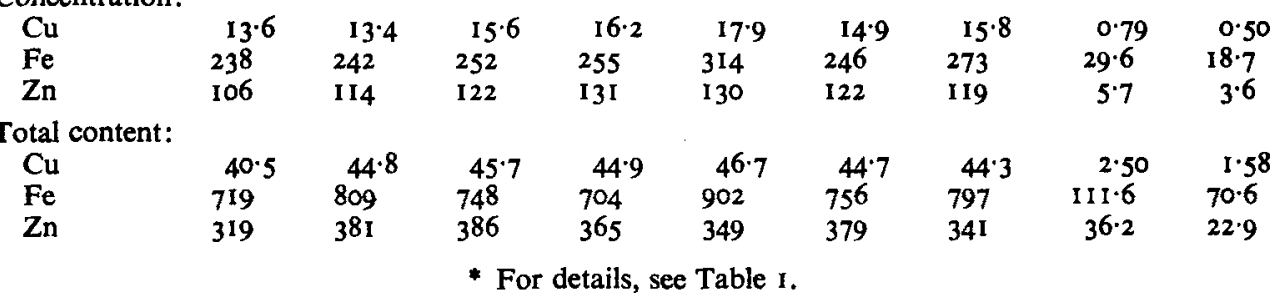

Table 6. Expt I. Oviduct and gizzard weights, intestinal and caecal lengths and weights of laying hens given $\mathrm{Cu}$-supplemented diets*

\begin{tabular}{|c|c|c|c|c|c|c|c|c|c|}
\hline \multirow[b]{3}{*}{ Added dietary $\mathrm{Cu}(\mathrm{mg} / \mathrm{kg}) \ldots$} & \multicolumn{5}{|c|}{ Diet no. } & \multirow{2}{*}{\multicolumn{2}{|c|}{ Breed no. }} & \multirow{2}{*}{\multicolumn{2}{|c|}{ SE of mean }} \\
\hline & & & & & & & & & \\
\hline & 0 & 200 & 400 & 600 & 800 & I & 2 & Diet & Breed \\
\hline $\begin{array}{l}\text { Fresh wt: } \\
\text { Oviduct (g) } \\
\qquad(\mathrm{g} / \mathrm{kg} \mathrm{BW})\end{array}$ & $\begin{array}{l}60 \cdot 8 \\
3 I \cdot 3\end{array}$ & $\begin{array}{l}59 \cdot 9 \\
31 \cdot 3\end{array}$ & $\begin{array}{l}55 \cdot 4 \\
30 \cdot 3\end{array}$ & $\begin{array}{l}57 \cdot 7 \\
34 \cdot 5\end{array}$ & $\begin{array}{l}49 \cdot 7 \\
31 \cdot 5\end{array}$ & $\begin{array}{l}59 \cdot 5 \\
28 \cdot 1\end{array}$ & $\begin{array}{l}53.9 \\
35.4\end{array}$ & $\begin{array}{l}3.59 \\
2 \cdot 17\end{array}$ & $\begin{array}{l}2 \cdot 27 \\
1 \cdot 37\end{array}$ \\
\hline $\begin{array}{l}\text { Gizzard (g) } \\
\qquad(\mathrm{g} / \mathrm{kg} \mathrm{BW})\end{array}$ & $\begin{array}{l}21 \cdot 8 \\
10 \cdot 9\end{array}$ & $\begin{array}{l}22 \cdot 3 \\
11 \cdot 5\end{array}$ & $\begin{array}{l}22 \cdot 0 \\
11 \cdot 9\end{array}$ & $\begin{array}{l}24 \cdot 9 \\
14 \cdot 8\end{array}$ & $\begin{array}{l}23 \cdot 4 \\
14 \cdot 5\end{array}$ & $\begin{array}{l}25 \cdot 3 \\
12 \cdot 0\end{array}$ & $\begin{array}{l}20 \cdot 4 \\
13 \cdot 4\end{array}$ & $\begin{array}{l}0.84 \\
0.45\end{array}$ & $\begin{array}{l}0.53 \\
0.28\end{array}$ \\
\hline $\begin{array}{l}\text { Intestine (g) } \\
\qquad(\mathrm{g} / \mathbf{k g ~ B W})\end{array}$ & $\begin{array}{l}27.8 \\
13.9\end{array}$ & $\begin{array}{l}25 \cdot 3 \\
13 \cdot 3\end{array}$ & $\begin{array}{l}29 \cdot 7 \\
15 \cdot 3\end{array}$ & $\begin{array}{l}30 \cdot 4 \\
19 \cdot 1\end{array}$ & $\begin{array}{l}32 \cdot 8 \\
21 \cdot 3\end{array}$ & $\begin{array}{l}34 \cdot 1 \\
16 \cdot 2\end{array}$ & $\begin{array}{l}24 \cdot 3 \\
17 \cdot 0\end{array}$ & $\begin{array}{l}1 \cdot 48 \\
1 \cdot 04\end{array}$ & $\begin{array}{l}0.94 \\
0.66\end{array}$ \\
\hline $\begin{array}{l}\text { Caecum (g) } \\
\qquad(\mathrm{g} / \mathrm{kg} \text { BW) }\end{array}$ & $\begin{array}{l}5 \cdot 2 \\
2 \cdot 6\end{array}$ & $\begin{array}{l}4 \cdot 5 \\
2 \cdot 3\end{array}$ & $\begin{array}{l}4 \cdot 7 \\
2 \cdot 5\end{array}$ & $\begin{array}{l}5 \cdot 4 \\
3 \cdot 4\end{array}$ & $\begin{array}{l}4 \cdot 9 \\
3 \cdot 2\end{array}$ & $\begin{array}{l}5 \cdot 8 \\
2 \cdot 7\end{array}$ & $\begin{array}{l}4 \cdot I \\
2 \cdot 8\end{array}$ & $\begin{array}{l}0.19 \\
0.12\end{array}$ & $\begin{array}{l}0.12 \\
0.07\end{array}$ \\
\hline $\begin{array}{l}\text { Length: } \\
\text { Intestine (mm) } \\
\qquad(\mathrm{m} / \mathbf{k g ~ B W})\end{array}$ & $\begin{array}{l}492 \\
0.250\end{array}$ & $\begin{array}{l}486 \\
0.253\end{array}$ & $\underset{0.256}{466}$ & $\begin{array}{l}497 \\
\quad 0.299\end{array}$ & $\begin{array}{l}483 \\
0.310\end{array}$ & $\begin{array}{l}507 \\
0.240\end{array}$ & $\begin{array}{l}463 \\
0.307\end{array}$ & $\begin{array}{l}20.6 \\
0.0152\end{array}$ & $\begin{array}{l}13 \cdot 0 \\
0.0096\end{array}$ \\
\hline $\begin{array}{l}\text { Caecum }(\mathrm{mm}) \\
(\mathrm{mm} / \mathrm{kg} \mathrm{BW})\end{array}$ & $\begin{array}{l}58 \\
29\end{array}$ & $\begin{array}{l}55 \\
29\end{array}$ & $\begin{array}{l}55 \\
30\end{array}$ & $\begin{array}{l}61 \\
37\end{array}$ & $\begin{array}{l}61 \\
39\end{array}$ & $\begin{array}{l}62 \\
29\end{array}$ & $\begin{array}{l}54 \\
36\end{array}$ & $\begin{array}{l}2 \cdot 6 \\
1.8\end{array}$ & $\begin{array}{l}1 \cdot 7 \\
\mathrm{~J} \cdot 2\end{array}$ \\
\hline
\end{tabular}


Using the staining techniques the presence of $\mathrm{Cu}$ was demonstrated only in the livers of birds given the diet containing $800 \mathrm{mg}$ added $\mathrm{Cu} / \mathrm{kg}$ diet.

\section{Expt 2}

None of the birds died during the course of the laying trial.

The body-weight and egg production results are shown in Table 7. Body-weight gain showed a significant quadratic relationship $(P<0.0 \mathrm{I})$ with the dietary content of added $\mathrm{Cu}$. All treatments resulted in a body-weight increase. This was greatest for $200 \mathrm{mg}$ added $\mathrm{Cu} / \mathrm{kg}$ diet and for treatment 5 was significantly depressed below all the other mean values. There was a quadratic relationship $(P<0.05)$ between food intake and the level of added $\mathrm{Cu}$ in the diet, the intake for treatment 5 being significantly depressed $(P<0.05)$ below that for treatments 3 and 4 . The mean food intake by treatment 3 or 4 hens was higher than for the other treatments in ten of the twelve periods.

There was a quadratic relationship between egg number and added dietary $\mathrm{Cu}$ for periods 3, 4 and 5. The number of eggs produced by the birds on the highest level of dietary $\mathrm{Cu}$ addition ( $400 \mathrm{mg} \mathrm{Cu} / \mathrm{kg}$ diet) was consistently the lowest. For the full experimental period the value for treatment $3(200 \mathrm{mg} / \mathrm{kg})$ was significantly higher $(P<0.05)$ than for treatment $5(400 \mathrm{mg} / \mathrm{kg})$ and statistical analysis showed the maximum egg number to occur at $176 \mathrm{mg}$ added $\mathrm{Cu} / \mathrm{kg}$ diet.

The over-all analysis showed that treatment $3(200 \mathrm{mg} / \mathrm{kg})$ gave the highest total egg weight (maximum for eight of the periods) and treatment $5(400 \mathrm{mg} / \mathrm{kg}$ ) the lowest (minimum for eleven of the periods), the values for treatments 3 and 4 being statistically greater $(P<0.05)$ than for treatment $5(400 \mathrm{mg} / \mathrm{kg})$. Calculation of the total egg weight response to added $\mathrm{Cu}$ gave a maximum at $15 \mathrm{I} \mathrm{mg} \mathrm{added} \mathrm{Cu} / \mathrm{kg}$ diet. Mean egg weight was highest for treatment 3 and lowest for treatment 5 and the maximum was found at $14 \mathrm{I} \mathrm{mg}$ added $\mathrm{Cu} / \mathrm{kg}$ diet.

Treatments 3 and 4 had the best mean efficiency of food conversion (maximum at $\mathrm{I} 6 \mathrm{I} \mathrm{mg}$ added $\mathrm{Cu} / \mathrm{kg}$ diet) while that for treatment 5 was the poorest, but none of the differences attained statistical significance.

The mean blood $\mathrm{Hb}, \mathrm{PCV}, \mathrm{Cu}$ and serum AAT results are presented in Table 8 . The $\mathrm{Hb}$ concentration and PCV were higher for all the $\mathrm{Cu}$-treated groups than for the control, this effect attaining significance for treatment $4 \mathrm{Hb}(300 \mathrm{mg} / \mathrm{kg})$. There was a linear relationship $(P<0.00 \mathrm{I}$ ) between blood $\mathrm{Cu}$ and level of added dietary $\mathrm{Cu}$, the values for treatments 4 and 5 being significantly greater $(P<0.001$ and $P<0.05$ respectively) than for the control.

Serum AAT showed a negative linear $(P<0.0 \mathrm{I})$ relationship to level of added dietary $\mathrm{Cu}$, the value at the highest level of added $\mathrm{Cu}$ being significantly lower $(P<0.05)$ than for treatments $I$ and 2.

Liver and kidney fresh and dry weights and DM results are given in Table 9 together with the oviduct and shell gland weights and the liver lipid values. Fresh and dry liver weights and liver DM content showed a negative linear $(P<0.001)$ response to level of added $\mathrm{Cu}$, and liver fresh weight per $\mathrm{kg}$ body-weight showed a quadratic response $(P<0.05)$, treatment $\mathrm{I}$ being significantly greater than all the other mean values. No such response was observed for kidney except as fresh kidney weight per $\mathrm{kg}$ body-weight when a linear response was noted $(P<0.05)$, the value for treatment 3 being lowest. As in Expt I the liver lipid concentration and total content decreased linearly (both $P<0.00 \mathrm{I}$ ) with the level of added dietary $\mathrm{Cu}$.

The $\mathrm{Cu}, \mathrm{Fe}$ and $\mathrm{Zn}$ results are given in Table I0. Only the concentration values are presented. As in Expt I liver DM Cu concentration showed a quadratic $(P<0.001)$ relationship to the level of added dietary $\mathrm{Cu}$. The $\mathrm{Fe}$ and $\mathrm{Zn}$ concentrations of the liver 
Table 7. Expt 2. Mean total food and supplementary copper intake, egg production, food conversion and body-weight of laying hens given Cu-supplemented diets*

Diet no.

\begin{tabular}{|c|c|c|c|c|c|c|c|c|c|}
\hline \multirow[b]{3}{*}{$\begin{array}{l}\text { Level of added } \mathrm{Cu} \\
\text { (mg/kg diet) ... }\end{array}$} & & \multirow{2}{*}{\multicolumn{2}{|c|}{ Breed no. }} & \multirow{2}{*}{\multicolumn{2}{|c|}{ SE of mean }} \\
\hline & & & & & & & & & \\
\hline & $\begin{array}{l}1 \\
0\end{array}$ & $\begin{array}{c}2 \\
100\end{array}$ & $\begin{array}{c}3 \\
200\end{array}$ & $\begin{array}{c}4 \\
300\end{array}$ & $\begin{array}{c}5 \\
400\end{array}$ & I & 2 & Diet & Breed \\
\hline $\begin{array}{l}\text { Total supplement- } \\
\text { ary } \mathrm{Cu} \text { intake (g) }\end{array}$ & 0 & 3.49 & $7 \cdot 16$ & 10.59 & 13.41 & - & - & - & - \\
\hline Food intake $(\mathrm{kg})$ & 35.06 & $34: 94$ & $35 \cdot 83$ & $35 \cdot 31$ & 33.51 & $36: 49$ & $33 \cdot 3^{8}$ & 0.629 & 0.398 \\
\hline Egg no. & $263 \cdot 3$ & 259.8 & $272 \cdot 4$ & 270.4 & $249 \cdot 5$ & 264.4 & $26 I \cdot 8$ & $8 \cdot 01$ & $5 \cdot 07$ \\
\hline Egg wt (kg) & $15 \cdot 38$ & $15 \cdot 13$ & $15 \cdot 73$ & 15.54 & $14 \cdot 01$ & $15 \cdot 40$ & 14.91 & 0.492 & 0.311 \\
\hline Mean egg wt (g) & $57^{\circ} 0$ & $56 \cdot 4$ & $57 \cdot 7$ & $56 \cdot 4$ & $56 \cdot 3$ & $58 \cdot 2$ & $55 \cdot 3$ & $1 \cdot 103$ & 0.698 \\
\hline $\begin{array}{l}\text { Efficiency of food } \\
\text { conversion (kg } \\
\text { eggs/kg food) }\end{array}$ & 0.434 & 0.429 & 0.439 & 0.439 & 0.417 & 0.421 & 0.442 & 0.0113 & 0.0072 \\
\hline $\begin{array}{l}\text { Initial body-wt } \\
(\mathrm{kg})\end{array}$ & $1 \cdot 68$ & $I \cdot 66$ & $1 \cdot 65$ & $I \cdot 64$ & $I \cdot 67$ & $1 \cdot 88$ & $1 \cdot 44$ & 0.028 & 0.018 \\
\hline $\begin{array}{l}\text { Body-wt change } \\
(\mathrm{g} / 28 \mathrm{~d} \text { period })\end{array}$ & 26 & $3 I$ & 28 & 23 & 15 & 29 & 19 & $2 \cdot 8$ & $I \cdot 7$ \\
\hline
\end{tabular}

Table 8. Expt 2. Mean blood haemoglobin $(H b)$, packed cell volume (PCV), copper and serum aspartate aminotransferase (AAT; EC 2.6. I I) for laying hens given Cu-supplemented diets*

Diet no.

\begin{tabular}{|c|c|c|c|c|c|c|c|c|c|}
\hline \multirow[b]{2}{*}{$\begin{array}{l}\text { Level of added } \\
\mathrm{Cu}(\mathrm{mg} / \mathrm{kg}) \ldots\end{array}$} & & & & & & \multicolumn{2}{|c|}{ Breed no. } & \multicolumn{2}{|c|}{ SE of mean } \\
\hline & $\begin{array}{l}\text { I } \\
0\end{array}$ & $\begin{array}{c}2 \\
100\end{array}$ & $\begin{array}{c}3 \\
200\end{array}$ & $\begin{array}{c}4 \\
300\end{array}$ & $\begin{array}{c}5 \\
400\end{array}$ & I & $\underbrace{}_{2}$ & Diet & $\overbrace{\text { Breed }}$ \\
\hline $\begin{array}{l}\mathrm{Hb}(\mathrm{g} / 1) \\
\mathrm{PCV}\end{array}$ & $\begin{array}{c}80.3 \\
0.26\end{array}$ & $\begin{array}{l}87.6 \\
0.27\end{array}$ & $\begin{array}{l}83 \cdot 1 \\
0 \cdot 26\end{array}$ & $\begin{array}{c}93.2 \\
0.29\end{array}$ & $\begin{array}{l}88 \cdot 7 \\
0.28\end{array}$ & $\begin{array}{c}84.4 \\
0.27\end{array}$ & $\begin{array}{r}88 \cdot 8 \\
0.28\end{array}$ & $\begin{array}{l}3.84 \\
0.011\end{array}$ & $\begin{array}{l}2 \cdot 43 \\
0.007\end{array}$ \\
\hline $\begin{array}{l}\mathrm{Cu}(\mu \mathrm{g} / \mathrm{l}) \\
\text { Serum AAT }\end{array}$ & $\begin{array}{l}266 \\
230\end{array}$ & $\begin{array}{l}279 \\
224\end{array}$ & $\begin{array}{l}296 \\
208\end{array}$ & $\begin{array}{l}324 \\
197\end{array}$ & $\begin{array}{l}307 \\
187\end{array}$ & $\begin{array}{l}292 \\
204\end{array}$ & $\begin{array}{l}297 \\
214\end{array}$ & $\begin{array}{l}\text { II } 3 \\
12 \cdot 0\end{array}$ & $\begin{array}{l}7 \cdot 2 \\
7 \cdot 6\end{array}$ \\
\hline
\end{tabular}

* For details, see Table I.

$\dagger$ One international unit refers to the oxidation of $1 \mu \mathrm{mol} \mathrm{NADPH} / \mathrm{min}$ at $37^{\circ}$.

DM increased linearly $(P<0.00 \mathrm{I}$ and $P<0.0 \mathrm{I}$ respectively) with increasing added dietary $\mathrm{Cu}$.

In the kidney DM Cu concentration showed a dietary effect $(P<0.00 \mathrm{I})$, the relationship being cubic. The kidney $\mathrm{Fe}$ concentration was not affected and kidney $\mathrm{Zn}$ concentration increased linearly $(P<0.00 \mathrm{I})$ with added dietary $\mathrm{Cu}$.

Treatment 5 oviduct weight (Table 9) showed a significant depression below the mean values of treatments I and 4 . On a body-weight basis treatment 4 had the heaviest oviduct weight, this being significantly greater than for treatment $2(P<0.001)$ and treatment 3 $(P<0.05)$. Oviduct DM content was not affected by treatment.

Oviduct $\mathrm{DM}, \mathrm{Cu}$ and $\mathrm{Fe}$ concentrations both showed a quadratic relationship $(P<0.0 \mathrm{I})$ to dietary added $\mathrm{Cu}$, while oviduct $\mathrm{Zn}$ concentration was not affected. Shell gland weight (Table 9) was not affected by diet. Gross and histological examination of the specific tissues investigated revealed no changes which could be attributed to dietary treatment. 
Table 9. Expt 2. Liver, kidney and oviduct fresh and dry weight, dry matter (DM) concentration and liver lipid levels for laying hens given $C u$-supplemented diets*

\begin{tabular}{|c|c|c|c|c|c|c|c|c|c|}
\hline \multirow[b]{2}{*}{$\begin{array}{l}\text { Level of added } \mathrm{Cu} \\
(\mathrm{mg} / \mathrm{kg} \text { diet }) \ldots\end{array}$} & \multicolumn{5}{|c|}{ Diet no. } & \multicolumn{2}{|c|}{ Breed no. } & \multicolumn{2}{|c|}{ SE of mean } \\
\hline & $\begin{array}{l}\text { I } \\
0\end{array}$ & $\begin{array}{c}2 \\
100\end{array}$ & $\begin{array}{c}3 \\
200\end{array}$ & $\begin{array}{c}4 \\
300\end{array}$ & $\begin{array}{c}5 \\
400\end{array}$ & I & 2 & Diet & Breed \\
\hline $\begin{array}{l}\text { Liver wt }(\mathrm{g}): \\
\quad \text { Fresh } \\
\text { Dry } \\
\text { Fresh }(\mathrm{g} / \mathrm{kg} \mathrm{BW})\end{array}$ & $\begin{array}{l}42.6 \\
15.8 \\
21.8\end{array}$ & $\begin{array}{l}39 \cdot 0 \\
14 \cdot 0 \\
19 \cdot 6\end{array}$ & $\begin{array}{l}36 \cdot 3 \\
12 \cdot 5 \\
18 \cdot 4\end{array}$ & $\begin{array}{l}37.3 \\
12.7 \\
19.9\end{array}$ & $\begin{array}{l}33 \cdot 6 \\
10 \cdot 7 \\
18 \cdot 8\end{array}$ & $\begin{array}{l}39.8 \\
13.7 \\
17.8\end{array}$ & $\begin{array}{l}35 \cdot 7 \\
12 \cdot 6 \\
21 \cdot 6\end{array}$ & $\begin{array}{l}1.57 \\
0.87 \\
0.67\end{array}$ & $\begin{array}{l}0.99 \\
0.55 \\
0.42\end{array}$ \\
\hline Liver DM $(\mathrm{mg} / \mathrm{g})$ & 366 & 350 & 335 & 331 & $3 I I$ & 334 & 343 & 8.63 & 5.46 \\
\hline $\begin{array}{l}\text { Liver lipid con- } \\
\text { tent }(\mathrm{mg} / \mathrm{g} \mathrm{DM})\end{array}$ & 383 & 344 & 288 & 292 & 249 & $30 I$ & 321 & $17 \cdot 7$ & II $\cdot 2$ \\
\hline $\begin{array}{l}\text { Total liver lipid } \\
\text { content }(\mathrm{g})\end{array}$ & 6.5 & $5 \cdot 3$ & 4.0 & $4 \cdot 1$ & $3 \cdot 0$ & $4 \cdot 6$ & 4.5 & 0.57 & 0.36 \\
\hline $\begin{array}{l}\text { Kidney wt }(\mathrm{g}) \text { : } \\
\text { Fresh } \\
\text { Dry } \\
\text { Fresh }(\mathrm{g} / \mathrm{kg} \mathrm{BW})\end{array}$ & $\begin{array}{c}10.4 \\
2.69 \\
5.40\end{array}$ & $\begin{array}{l}10 \cdot 5 \\
2.65 \\
5.58\end{array}$ & $\begin{array}{l}10 \cdot 1 \\
2.58 \\
5.22\end{array}$ & $\begin{array}{l}11 \cdot 3 \\
2 \cdot 86 \\
6 \cdot 14\end{array}$ & $\begin{array}{l}10.3 \\
2.54 \\
5.97\end{array}$ & $\begin{array}{l}10 \cdot 2 \\
2.65 \\
4.61\end{array}$ & $\begin{array}{l}10 \cdot 8 \\
2.68 \\
6 \cdot 72\end{array}$ & $\begin{array}{l}0.31 \\
0.082 \\
0.262\end{array}$ & $\begin{array}{l}0.20 \\
0.052 \\
0.166\end{array}$ \\
\hline Kidney DM (mg/g) & 257 & 254 & 256 & 253 & 248 & 259 & 249 & $4 \cdot 35$ & $2 \cdot 75$ \\
\hline $\begin{array}{l}\text { Oviduct wt } \\
\text { (g) } \\
(\mathrm{g} / \mathrm{kg} \mathrm{BW})\end{array}$ & $\begin{array}{l}57 \cdot 0 \\
29 \cdot 6\end{array}$ & $\begin{array}{l}53.5 \\
26.7\end{array}$ & $\begin{array}{l}55.2 \\
28.5\end{array}$ & $\begin{array}{l}58 \cdot 5 \\
31 \cdot 9\end{array}$ & $\begin{array}{l}52 \cdot 7 \\
30 \cdot 5\end{array}$ & $\begin{array}{l}55.2 \\
25.0\end{array}$ & $\begin{array}{l}55.5 \\
33.9\end{array}$ & $\begin{array}{l}1 \cdot 79 \\
1.06\end{array}$ & $\begin{array}{l}1 \cdot 13 \\
0.67\end{array}$ \\
\hline $\begin{array}{l}\text { Shell gland wt } \\
\quad(\mathrm{g}) \\
(\mathrm{g} / \mathrm{kg} \mathrm{BW})\end{array}$ & $\begin{array}{r}16 \cdot 2 \\
8 \cdot 5\end{array}$ & $\begin{array}{r}15.9 \\
7.9\end{array}$ & $\begin{array}{r}15 \cdot 3 \\
7 \cdot 8\end{array}$ & $\begin{array}{r}16 \cdot 0 \\
8.7\end{array}$ & $\begin{array}{r}15.9 \\
9.2\end{array}$ & $\begin{array}{r}15.6 \\
7.0\end{array}$ & $\begin{array}{r}16.0 \\
9.8\end{array}$ & $\begin{array}{l}0.62 \\
0.36\end{array}$ & $\begin{array}{l}0.39 \\
0.23\end{array}$ \\
\hline
\end{tabular}

Table 10. Expt 2. The copper, iron and zinc concentration $(\mu \mathrm{g} / \mathrm{g})$ in liver, kidney and oviduct DM of laying hens given Cu-supplemented diets*

Diet no.

Level of added $\mathrm{Cu}$

(mg/kg diet) ...

$\overbrace{\begin{array}{ccccc}1 & 2 & 3 & 4 & 5\end{array}}^{\text {Diet no. }} \overbrace{1}^{\text {Breed no. }} \overbrace{2}^{\text {SE of mean }}$

Liver dry matter

Concentration:

$\mathrm{Cu}$

$\mathrm{Fe}$

$\mathrm{Zn}$

$\begin{array}{llllllllc}10 \cdot 2 & 12 \cdot 0 & 13 \cdot 8 & 14 \cdot 5 & 26 \cdot 3 & 14 \cdot 6 & 16 \cdot 1 & 1 \cdot 18 & 0 \cdot 74 \\ 250 & 291 & 323 & 297 & .407 & 336 & 292 & 26 \cdot 5 & 16 \cdot 8 \\ 102 & 102 & 118 & 109 & 141 & 118 & 111 & 8 \cdot 2 & 5 \cdot 2\end{array}$

Liver lipid-free dry matter

Concentration:

$\mathrm{Cu}$

$\mathrm{Fe}$

$\mathrm{Zn}$

$\begin{array}{lllllllcc}16 \cdot 4 & 17 \cdot 7 & 19 \cdot 1 & 20 \cdot 4 & 34 \cdot 3 & 20 \cdot 4 & 22 \cdot 8 & 1 \cdot 27 & 0 \cdot 80 \\ 400 & 438 & 452 & 421 & 533 & 476 & 422 & 33 \cdot 3 & 21 \cdot 1 \\ 165 & 153 & 163 & 152 & 185 & 166 & 161 & 9 \cdot 2 & 5 \cdot 8\end{array}$

Kidney dry matter

Concentration:

$\mathrm{Cu}$

$$
\mathrm{Zn}
$$

Oviduct dry matter

Concentration:

$\mathrm{Cu}$

$\mathrm{Zn}$

n

$\begin{array}{rllllllll}14 \cdot 7 & 2 I \cdot 4 & 14 \cdot 7 & 17 \cdot 6 & 20 \cdot 2 & 17 \cdot 4 & 18 \cdot 1 & 0.98 & 0.62 \\ 254 & 262 & 250 & 274 & 288 & 251 & 280 & 13 \cdot 0 & 8 \cdot 2 \\ 105 & 106 & 108 & 111 & 118 & 108 & 111 & 2 \cdot 4 & 1 \cdot 5\end{array}$

$\begin{array}{cllllllll}6 \cdot 3 & 12 \cdot 0 & 9 \cdot 3 & 10 \cdot 6 & 8 \cdot 1 & 8 \cdot 7 & 9 \cdot 8 & 1 \cdot 03 & 0.65 \\ 41 & 56 & 56 & 65 & 50 & 51 & 56 & 6.6 & 4 \cdot 2 \\ 47 & 47 & 47 & 48 & 47 & 45 & 49 & 1 \cdot 9 & 1 \cdot 2\end{array}$

* For details, see Table I. 


\section{DISCUSSION}

The tolerance of the laying hen to the high levels of dietary Cu used in Expt I over the fairly long-term period involved and to the even higher levels used previously (Jackson, 1977) was unexpected and in contrast to the low tolerance shown by the ruminant (Shand \& Lewis, 1957; Todd \& Thompson, 1963) and even by the pig (Suttle \& Mills, I966 $a, b$ ).

The increase in food intake at the lower levels of $\mathrm{Cu}$ intake observed in the initial experiment of this series (Jackson, 1977) is again evident, as is the depression of food intake at the higher levels of addition, a $33 \%$ fall in food intake being observed at the highest level. Since the diets were isonitrogenous and isocaloric, the marked depression of food intake, especially at the highest level of $\mathrm{Cu}$ addition, is apparently due to the presence of the $\mathrm{Cu}$. The current work does not help clarify whether this effect is due to $\mathrm{Cu}$ toxicity or to palatability. Even though the domestic fowl is reported to have relatively few taste buds compared with other species (Kare \& Rogers, 1976) it cannot be ruled out that the quadratic effect of $\mathrm{Cu}$ on food intake may be due, at least partially, to a palatability effect. The results for body-weight gain showed that the higher levels of added $\mathrm{Cu}(400-800 \mathrm{mg} / \mathrm{kg})$ caused a definite decrease while the lower levels had no marked effect. The linear decrease of bodyweight gain found in Expt I agrees with the results of Jackson (1977) and Goldberg et al. (1956) for hens. In the former work a considerable loss of body-weight was attributed to liver weight loss and oviduct regression, but in the current experiments these were not important factors. In Expt I the decrease of body-weight gain at 600 and $800 \mathrm{mg}$ added $\mathrm{Cu} / \mathrm{kg}$ is clearly due to the decrease of food intake ( 16 and $33 \%$ respectively). From the first day of Expt I the $200 \mathrm{mg}$ added $\mathrm{Cu} / \mathrm{kg}$ level had a small stimulatory effect and the higher levels a definite negative effect on intake. Although for the first 2 weeks the presence of added $\mathrm{CuSO}_{4}$ in the diet had opposite effects on water intake for the two breeds of hens used, overall the highest level used caused a depression of water intake. This effect agrees with that observed previously (Jackson, 1977).

The quadratic response of egg number and total egg weight to dietary $\mathrm{CuSO}_{4}$ in Expt I was apparent to a lesser extent in Expt 2, although there is no obvious explanation as to why the breed effect for egg number found in the first experiment was not present in the second experiment. The results substantiate the production values presented by Jackson ( 1977 ) based on a small number of hens given $\mathrm{Cu}$-containing diets for a short ( 5 weeks) period.

Examination of the ovaries, oviducts and the laying records of the hens in both experiments showed that treatment had no effect on the number of birds found to have an inactive reproductive system. However, in Expt I, once the hens were introduced to the Cucontaining diets those on treatment 2 showed an immediate and sustained increase in egg number and those on treatments 4 and 5 showed a very definite decrease. The effect in these two groups was fairly consistent for each bird and not due to complete cessation of laying by a proportion of the birds. The effect found at 600 and $800 \mathrm{mg}$ added $\mathrm{Cu} / \mathrm{kg}$ diet is similar to that found previously (Jackson, 1977) when at $960 \mathrm{mg} / \mathrm{kg}$ production became infrequent, but differs from the effect at $1920 \mathrm{mg} / \mathrm{kg}$ when laying ceased after a short time.

In both experiments the $200 \mathrm{mg} / \mathrm{kg}$ level gave the highest mean egg weight, while at the highest level used a depression was evident. However, it is not clear why the maximum in Expt $\mathrm{I}$ occurred at $235 \mathrm{mg}$ added $\mathrm{Cu} / \mathrm{kg}$ diet while in Expt 2 the maximum point of the response curve was at $\mathrm{I} 4 \mathrm{I} \mathrm{mg}$ added $\mathrm{Cu} / \mathrm{kg}$ diet.

As for egg number, the breed effect for efficiency of food conversion for egg production found in Expt I (maximum for breed I, $263 \mathrm{mg}$ added $\mathrm{Cu} / \mathrm{kg}$ diet; for breed 2, $220 \mathrm{mg}$ added $\mathrm{Cu} / \mathrm{kg}$ diet) was not present in Expt 2 (maximum I6I $\mathrm{mg}$ added $\mathrm{Cu} / \mathrm{kg}$ diet). The reason for the maximum response occurring at a lower level of $\mathrm{CuSO}_{4}$ addition in 
the latter experiment is not readily explained but could be due to various environmental differences between the experiments. That the positive effect of added dietary $\mathrm{CuSO}_{4}$ on egg production may be similar to that observed when antibiotics are used as food additives is not supported by the intestinal weight and length values, which increase when presented on a unit body-weight basis, while antibiotics in the diet have been shown to decrease intestinal weight and thickness in growing fowl (Gordon, 1952; March \& Biely, 1967) and pigs (Braude et al. 1955; Taylor \& Harrington, 1955). King (1972) gave diets containing added $\mathrm{Cu}$ (100 mg as sulphate $/ \mathrm{kg}$ ) to chicks and found decreased small intestinal weight which was accompanied by increased caecal weight, this latter effect being observed in Expt $I$. Nevertheless the response of the intestine to high dietary $\mathrm{CuSO}_{4}$ in the mature hen need not necessarily be the same as the response found to lower levels in the younger growing animal.

The results for blood $\mathrm{Cu}$ content were not consistent in that in Expt $\mathrm{I}$, as in a previous experiment (Jackson, I977), no significant differences occurred, while in Expt 2 the 300 and $400 \mathrm{mg} / \mathrm{kg}$ levels caused a small but statistically significant increase over the control value. Goldberg et al. (1956) and Kuznetsov \& Volkov (1974) found that Cu salts in the diet of adult hens caused increased blood $\mathrm{Cu}$ concentration. The conditions in the latter work were not dissimilar to the present experiments in that it involved long-term feeding $(270 \mathrm{~d})$ of the $\mathrm{CuSO}_{4}$-containing diet. The results tend to support the theory that, as for $\mathrm{Fe}$, the animal has a barrier mechanism for limiting its $\mathrm{Cu}$ absorption.

The depressed $\mathrm{Hb}$ for treatment 5 compared to the values for treatments 2 and 3 in Expt $\mathrm{I}$ indicates some agreement with the results of Ruszczyc et al.(1962) and Kirchgessner et al. (1970) for the chick, although the very different hormonal status of the chick and laying hen and the long-term feeding period in the present experiments rather invalidate any comparison.

In Expt I no definite effect on serum AAT could be identified although in Expt 2 the evidence strongly indicated a depressing effect of dietary $\mathrm{Cu}$ on serum AAT level, but there was no evidence of the elevated serum AAT levels associated with stress or dysfunction of liver in the human (Norberg, I96I) or sheep (Todd \& Thompson, 1963).

The depression of liver weight in response to dietary $\mathrm{Cu}$ appears to be related to the lower body-weight, although when expressed on a unit body-weight basis there was still some indication of a depression, especially in Expt 2. The liver lipid content was depressed in both experiments as a result of high dietary $\mathrm{Cu}$, indicating a possible depression of fatty acid and lipid synthesis, which in the fowl occur mainly in the liver (Ranney \& Chaikoff, 195I; Goodridge, I968; O'Hea \& Leveille, 1969). The fact that, on a body-weight basis, oviduct weight was not depressed by $\mathrm{Cu}$ level does not suggest that there was any major effect on the secretion or action of the gonadotrophins or the steroid hormones associated with normal development of the reproductive system. Any effect on egg production is probably associated with increased or decreased nutrient intake and efficiency of food conversion rather than with an effect on the reproductive endocrine system.

The results of the staining technique for $\mathrm{Cu}$ (Lindquist, 1969) agree with the quantitative results. The liver $\mathrm{Cu}$ concentrations reported here and previously (Jackson, I977) suggest that there is a critical point between 600 and $800 \mathrm{mg}$ added $\mathrm{Cu} / \mathrm{kg}$ at which liver $\mathrm{Cu}$ concentration rises sharply.

The liver $\mathrm{Fe}$ and $\mathrm{Zn}$ concentrations in both experiments showed a positive linear response to increasing dietary $\mathrm{Cu}$. The increased liver $\mathrm{Fe}$ is contrary to the results found in the pig, where high levels of dietary $\mathrm{Cu}$ caused reduced Fe storage (Cassidy \& Eva, 1958; Ritchie et al. 1963) and is at variance with the anaemia observed in chicks given a high level of dietary $\mathrm{Cu}$ (Ruszczyc et al. 1962), but does agree with the increase found previously for the mature bird (Jackson, 1977). The increase in liver $\mathrm{Zn}$ concentration is in conformity with 
the observation that $\mathrm{Cu}$ has a $\mathrm{Zn}$-sparing effect in the pig (Wallace et al. 1960; Ritchie et al. 1963) although a contrary result has been found by others (O'Hara et al. I960; Suttle \& Mills, $1966 b$ ).

The results both of the laying trial and the associated observations and those obtained by gross and histological examination of the various tissues indicate that at the lower levels used the presence of $\mathrm{CuSO}_{4}$ in the diet for an extended period of time has a beneficial effect on production and food conversion, and although these factors were adversely affected at high levels of addition there was no definite evidence of pathological changes, the increased gizzard, intestine and caecal weights indicating a response to the presence of the $\mathrm{CuSO}_{4}$.

The loss of feathers noted in Expt I was more prevalent in the white (Shaver 288) than in the brown (Warren Studler SSL) birds and could markedly increase heat loss (O'Neill \& Jackson, 1974).

The authors thank Mrs R. Park and Mr P. Shearer for technical assistance, Dr S. T. C. Weatherup of the Biometrics Division for assistance with statistical analyses and Dr R. M. McCracken for the histological examinations.

\section{REFERENCES}

Bergmeyer, H. U. \& Bernt, E. (1965). In Methods of Enzymatic Analysis, pp. 837-53 [H. U. Bergmeyer, editor]. Weinheim: Verlag Chemie.

Braude, R., Coates, M. E., Davies, M. K., Harrison, G. F. \& Mitchell, K. G. (1955). Br. J. Nutr. 9, 363.

Bubien, Z., Morand, M., Gastellu, J. \& Magat, A. (197I). Revue Méd. vét. 122, 51 I.

Cassidy, J. \& Eva, J. K. (1958). Proc. Nutr. Soc. 17, xxxi.

Fisher, C. (1973). Feedstuffs 45 no. 25, 24.

Fisher, C., Laursen-Jones, A. P., Hill, K. J. \& Hardy, W. S. (1973). Br. Poult. Sci. I4, 55.

Fisher, C., Wise, D. \& Filmer, D. G. (1971). I4th Wld's Poult. Congr., Madrid 759.

Folch, J., Lees, N. \& Sloane Stanley, C. H. (I957). J. biol. Chem. 226, 497.

Goldberg, A., Williams, C. B., Jones, R. S., Yanagita, M., Cartwright, G. E. \& Wintrobe, M. M. (1956). J. Lab. clin. Med. 48, 442 .

Goodridge, A. G. (I968). Am. J. Physiol. 214, 897.

Gordon, H. A. (1952). Report from Lobund Institute. University of Notre Dame, Indiana.

Griminger, P. (1977). Poult. Sci, 55, 359.

Jackson, N. (1977). Br. J. Nutr. 38, 93 .

Janssen, W. M. M. A. (I971). Arch. Gefugelk 35, 137.

Jensen, L. S., Chang, C. H. \& Wilson, S. P. (1978). Poult. Sci. 57, 648.

Jensen, L. S. \& Maurice, D. V. (1978). Poult. Sci. 57, 166.

Kare, M. R. \& Rogers, J. G. (1976). Sense organs. In Avian Physiology, pp. 29-52 [P. D. Sturkie, editor]. 3rd ed. Springer-Verlag.

King, J. O. L. (1972). Br. Poult. Sci. 13, 61.

Kirchgessner, M., Hampel, G. \& Roth-Maier, D. A. (1970). Z. Tierphysiol, Tierernährung Futtermittelk. 26, 279.

Kuznetsov, S. G. \& Volkov, D. T. (1974). Vop. Pitan. 6, 5 I.

Lindquist, R. R. (1969). Archs Path. 87, 370.

March, B. E. \& Biely, J. (1967). Poult. Sci. 46, 831.

Norberg, B. (1961). Clinica chim. Acta 6, 264.

O'Hara, P. J., Newman, A. P. \& Jackson, R. (1960). Aust. vet. J. 36, 225.

O'Hea, E. K. \& Leveille, G. A. (1969). Comp. Biochem. Physiol. 30, I 49.

O'Neill, S. J. B. \& Jackson, N. (1974). J. agric. Sci., Camb. 82, 549.

Ranney, R. E. \& Chaikoff, I. C. (1951). Am. J. Physiol. 165, 600.

Ritchie, H. D., Luecke, R. W., Baltzer, B. V., Miller, E. R., Ullrey, D. E. \& Hoefer, J. A. (I963). J. Nutr. 79, 117.

Ruszczyc, Z., Preś, J. \& Fritz, Z. (1962). Rocz. Nauk rol. 81, 49.

Shand, A. \& Lewis, R. (1957). Vet. Rec. 69, 618.

Suttle, N. F. \& Mills, C. F. (I966a). Br. J. Nutr. 20, 135.

Suttle, N. F. \& Mills, C. F. (I966b). Br. J. Nutr. $20,149$.

Taylor, J. H. \& Harrington, G. (1955). Nature, Lond. 175, 643.

Thompson, R. H. \& Blanchflower, W. J. (I97I). Lab. Pract. 20, 859.

Todd, J. R. \& Thompson, R. (I963). Br. vet. J. Ir9, I6I.

Wallace, H, D., McCall, J. T., Bass, B. \& Combs, G. E. (1960). J. Anim. Sci. 19, I 53. 